\title{
MAHOMMEDAN SLAVS
}

TU

URKISH dominance may have been curbed in Europe by the Great War-we know that it is being allowed to run riot in Asia-but it would be a mistake to think that the canker of Islamism has been removed. The new kingdom of Serbs, Croats and Slovenes has in its midst approximately one million Sons of the Prophet. Their main stronghold is in Bosnia, together with Herzegovina, where Moslem bigotry and cruelty earned for it a title of which it was proud until yesterday: "The Lion that guards Stambul against the West.' Yet Bosnia was a Christian land five centuries ago, and the story of Bosnian heroism in religious fidelity, after the lapse of its Christian leaders, has not yet been given to the world. The landlords, forebears of the present arrogant and tyrannous Begs, became apostates to Islam for the sake of their lands and titles. Their Christianity had been already undermined at the time of the Turkish invasion by the heretical tenets of the Bogumiles, a sect that had much in common with the Protestantism of later days. English writers are found who excuse the Bosnian chieftains for their preference of the Sultan's jurisdiction to that of the Pope. The harsh measures meted out to heretics in the Middle Ages were here intensified by rivalry between Bosnian chiefs who denounced each other to the King of Hungary, or the Rulers of Venice and Ragusa, and were perverts or converts as the situation required, now submitting to Rome, next day repudiating submission. These tactics have been faithfully followed by their descendants, who reminded the Sultan on more than one occasion that their ancestors were Christians, and that they might themselves, if thwarted in their justified claims, return to the old faith! This defiant note was sounded more especially after the establishment 28 


\section{Mahommedan Slavs}

of Serbia as a Christian, quasi-independent State, and whenever a small band of Montenegrins gained another of their startling triumphs over the Sultan's troops. The Begs profited of every event to make sure they got the full price of Christ's betrayal, but certainly, whatever idle threats they may have at times uttered, they have kept the pact of fanatic devotion to Islam. A natural sympathy, founded on pride in a common nationality, made them watch the Montenegrin struggle at their doors and hold aloof instead of abetting the forces of Allah to quell it. They readily marched against other Christians of the Peninsula, and wrought havoc among the Christians of Asia, but when approached by the Serbs of Serbia or Montenegro they replied: 'We belong to the Prophet and will not swerve from him. We can make no alliance with non-believers.'

The chances for the rebels were still too problematical for the wary Begs, many of whom preserve in their castles documents dating from Christian times to prove their rights as owners. In spite of the horrible oppression of the Christian population on whom the Bosnian Mahommedans battened with a fury unknown to the Turks, Christian tradition survived, and is at present extant among the renegades. Their women-folk believe in the efficacy of Christian emblems and visit Christian shrines where, like the poor 'rayah' who have held the Faith throughout centuries of suffering, they lay their sick babe on hallowed stones and pray for its recovery. Even here the 'rayah' moved aside to make room for the superior caste. The word 'rayah' literally means one reprieved, one who, having forfeited life, is still permitted to live by the clemency of the 'true believers.' The Begs had power of life and death over their Christian vassals, but a Christian who in a quarrel, or by accident, or in self-defence, killed a Mussulman was 


\section{Blackfriars}

immediately executed. Forty years ago the word of a Christian had no value in a Turkish law-court. He dared not ornament his dress nor dwelling. He dared not ride if a Mussulman was in sight on foot. When admitted to the presence of a Beg the 'rayah' first fell on his hands and knees and then stated his petition. No wonder that the 'rayah' was decried by thoughtless tourists as mean-looking, furtive, dirty, shabby, and altogether a poor specimen of humanity, whereas the dignified, commanding, knightly Mahommedan Beg inspired respect and admiration. The Bosnian Beg has, indeed, a fine appearance. He is noted for his snowy linen and the cleanliness of his home. Unlike the demoralised Turks, he does not shirk the ablutions enjoined in the Koran by letting a few drops of water trickle from wrist to elbow, and -for feet-washing-salve his conscience by sprinkling his boots. The Beg performs conscientiously all rites. Also he is magnificently attired in crimson cloth embroidered with gold; steed, and jewelled sword in keeping. When with his mounted suite he paced slowly through his Christian villages no wonder the hypnotised slaves looked with awe on the flourishing seed of apostacy. Silken attire is not out of place for a man with countless slaves to weave it for him and robe him in it. Stately cohorts, when a Beg rides forth, still wind their way through the hills of Bosnia. Granted, what is not proved, that the miserable ravahs be liars, thieves, slayers when they dare, any Western critic should stoop and kiss their feet for the mere fact that they even call themselves Christians. Whether through atavism-their forefathers were serfs at the time of the Turkish onslaught-or through prudence or mere cowardice-the rayahs fought for their Beg and often served him faithfully against his enemies. They were not asked to fight against the Montenegrins, their neighbours and brothers. In pur- 


\section{Mahommedan Slavs}

suance of their inherited policy the Begs accentuated race instead of creed as they found it expedient. All Bosnians are proud of kinship with the brave, unconquerable people of Montenegro, who held to their faith as the Begs had done to their castles, and dwelt aloft in their eyries of black, barren stone rather than bend to a conqueror. In physique there is little difference between the two, although the Montenegrin has empty pockets, meagre fare, and a bare home, while the Bosnian Mahommedan feeds well, has a full purse, and a sumptuous dwelling. Any comparison between the Montenegrins and their fellow-Christians of Bosnia would be painful and unfair. The moral gap that divides freemen from slaves is evident here as elsewhere. Nevertheless the Bosnian rayah, trained from childhood to grovel before his masters, sons of apostates, knew that not far off his Montenegrin brother had the peculiarity of never prostrating himself, and that he 'walked like a Beg!' Indeed, the Montenegrin Serb is not given to saluting, and when he greets is careful not to bend his spine. Even in the little church he has fought so hard to retain he roes not, as a rule, kneel, but talks to the Almighty with head erect. His weapons have been left outside, to be resumed as he leaves, for how could he tell when he may be called to use them on 'the foes of Christ'? No wonder the Begs, although at times on a friendly footing with the Montenegrin chiefs, disliked intercommunication lest the rayahs, mere adjuncts of their lords, should see Christians treated by these on an equal footing, the only one possible in dealing with the poorest of Montenegrins. There is no doubt that whenever the rayahs became insubordinate, incitement could be traced to Montenegro. The call went forth half a century ago from the border tribe of Vassoyevitch, harried beyond endurance for tribute by the Sultan's troops :- Every son of a Serbian Mother, 


\section{Blackfriars}

Come out for freedom!' It is said that among the volunteers from Bosnia there were Mahommedans as well as Christians, but neither came in sufficient numbers to affect the course of events. The insurrection was successful, but the boundary line was drawn, at Austria's bidding, according to creed. Then the Catholic Vassoyevitches refused, even under Austrian protection, to remain part of Turkey, and another insurrection shortly afterwards united them definitely to Montenegro. A Montenegrin who approached a friendly Beg of Bosnia for help in the struggle got the following reply, which shows clearly the same mentality as that of the men who abjured Christ at Kossovo:-

'Ties of brotherhood are strong, but your Prince is so poor that his soldiers have to feed themselves. Moreover, they get no pay. The Sultan we serve keeps our men well-fed, well-clad, and well-paid. Why should we starve and fight for you? It is enough that we will not march against you; nor does the Sultan expect it of us. We remain in his service.'

But the Bosnians managed to draw profit for themselves out of the Montenegrin successes. The Begs respected the Ruling House of Montenegro, and blotted from memory the acts of Danilo, founder of the dynasty. Danilo escaped from a Turkish prison to rouse his people and confirm the aggressive spirit that, to his mind, could alone preserve them from a choice between extermination and apostacy. $\mathrm{He}$ bade them slay at sight any Mahommedan that entered the territory of the Black Mountain, and still more ruthlessly to slay at home, or elsewhere, wherever met, any Christian who had renounced his $F$ aith for Mahommedanism. To these fierce methods of self-preservation, methods that Western minds can with difficulty excuse or palliate, Montenegro owes to-day her immunity from the grave troubles existent in the sister 


\section{Mahommedan Slavs}

lands of Bosnia and Herzogovina corroded by the canker of Mahommedanism. One can say with truth that it is owing to the attitude of Montenegro, and of the more distant little Principality of Serbia, that the Christian survivors in Bosnia finally took heart to assert their human rights. Austria's occupation of the disturbed provinces after the rising of 1878 was a useful transition period for the Moslem element; but the proclamation of absolute equality in all things between landlord and rayah by the present Government of Yugoslavia is a bitter pill for that body of despots. The indignation of the Begs has not yet subsided.

'We found,' said the Cabinet Minister, Dr. Velizar Jankovic, in a recent speech, ' that the lands held by the Dual Monarchy contained hundreds of thousands of serfs, our brothers, and it was difficult to decide which task called to us first: the emancipation of these victims of feudalism established by Turkey, and tolerated by a great State known as Christian; or the relief of our own poor warriors returning extenuated or crippled to plundered, desolate homes. Well, we gave our first attention to the Bosnian peasant, and decreed the agrarian reform that made him a freeman, owner, exactly like his Serbian brother, of the soil he tills.'

The State expenditure in connection with this measure of reform was considerable. The incensed Begs were not content with compensation for their financial loss, but demanded also money equivalent for their declined prestige. They are now engaged in bartering such political principles as they possess to party leaders in the Belgrade Parliament, just as their ancestors long ago offered their religion in exchange for the favours of the Sultan. Their power is not broken; for their vote is courted by all parties in the State. Their mosques are studded all over Bosnia 


\section{Blackfriars}

and Herzegovina in as absurd proportion to their numbers when compared with the Christian majority as the Protestant churches in Ireland when the Catholics paid tithe for the erection and upkeep of these alien temples.

What will be the ultimate fate of Islamism in Bosnia? Will it fade now it is politically severed from Constantinople? Needless to say there are certain elements at home and abroad who look with complacency on this anti-Christian phalanx, and will employ it for their own ends. The prospect of a return to the Faith of their Fathers-such as it wasis unthinkable for any but a mercenary motive on the part of the Bosnian Mahommedans.

The Catholics in Bosnia and Herzegovina have a glorious record. The survival of the Franciscans of Sutyeska is a striking example of God's protection of his faithful servants. The friars obtained from the Sultan who subdued the land in 1484 a firman guaranteeing that they should not be molested, and although this immunity did not last more than a century, and at one time the monastery was destroyed and its inmates driven for shelter to caves and forests, they never ceased to minister to the spiritual wants of their flock. As time went on they again crept forth, rebuilt their house and extended their activities. The Franciscans, assisted at a later date by the Jesuits, were the mainstay of Catholicism in Bosnia and Herzegovina. Their recently-deceased Provincial, Fra Didak Buntic, was a good illustration of the type of man that gained the confidence and love of his compatriots. This worthy son of St. Francis showed his solicitude for religious cult and education by laving the foundations of a splendid church and a college on the heights 'Siroga Brega' outside Mostar, capital of Herzegovina, while at the same time he fostered the economic interests of the people. He 


\section{Mahommedan Slavs}

taught them the best way of cultivating the tobacco plant, and how to improve their old-fashioned methods of tilling and harvesting. He was an enthusiastic advocate of racial reunion, and went as elected representative to the first parliamentary assembly in Belgrade of the Southern Slavs. At the present moment there is an energetic Catholic League, his foundation, with headquarters at Zagreb (Agram), whose title, 'Napredak' (Progress), augurs well for the future of Catholicism in the main field of its labours: Bosnia, once a stronghold of Mahommedanism.

E. Christitch. 